
ISSN : 2615-1995, E-ISSN : 2615-0654

J. Madani., Vol. 3, No. 2, September 2020 (202 - 211)

C2018 Lembaga Kajian Demokrasi

dan Pemberdayaan Masyarakat (LKD-PM)

DOI : https://doi.org/10.33753/madani.v3i2.115

\title{
Pengaruh Budaya Organisasi Terhadap Kinerja Karyawan Pada PT Bank Negara Indonesia KCP Pamulang Tangerang Selatan
}

\author{
Angga Pratama \\ Fakultas Ekonomi, Universitas Pamulang \\ dosen02155@unpam.ac.id
}

\begin{abstract}
Abstrak
Tujuan penelitian ini untuk mengetahui bagaimana budaya organisasi pada PT Bank negara Indonesia KCP Pamulang Tangerang Selatan, mengetahuai bagaimana kinerja karyawan pada PT Bank Negara Indonesia KCP Pamulang Tangerang Selatan dan mengetahui pengaruh budaya organisasi terhadap kinerja karyawan, pada PT Bank Negara Indonesia KCP Pamulang Tangerang Selatan. Jenis penelitian ini adalah penelitian deskriptif asosiatif. Populasi dan sampelnya adalah seluruh karyawan PT Bank Negara Indonesia KCP Pamulang Tangerang Selatan. Dalam penelitian ini dilakukan dengan menggunakan bantuan program SPSS ver. 23 yaitu meliputi uji kualitas data, uji regresi linier sederhana, uji koefisien korelasi, uji hipotesis dan uji koefisien determinasi. Hasil penelitian ini menunjukkan bahwa budaya organisasi pada PT Bank Negara Indonesia KCP Pamulang Tangerang Selatan sudah baik yaitu dengan jawaban seluruh responden yang berjumlah 50 karyawan dengan "Sangat Setuju" sebanyak 146 atau 29\%, jawaban "Setuju" sebanyak 262. Kinerja karyawan pada PT. Bank Negara Indonesia KCP Pamulang Tangerang Selatan sudah baik yaitu dengan jwaban seluruh responden yang berjumlah 50 karyawan yang menjawab "Sangat Setuju" sebanyak 177 atau 35\%, jawaban "Setuju" sebanyak 254 atau 51\%. Budaya organisasi berpengaruh signifikan terhadap kinerja karyawan pada PT Bank negara Indonesia KCP Pamulang Tangerang Selatan dengan nilai thitung lebih besar dari nilai ttabel $(7,045>1,67)$ dan signifikansi lebih kecil dari 0,05 $(0,00<0,05)$.
\end{abstract}

Kata Kunci : Budaya Organisasi, Komitmen Organisasi, Kinerja Karyawan

\begin{abstract}
The purpose of this study was to determine how the organizational culture of PT Bank Negara Indonesia KCP Pamulang Tangerang Selatan, find out how the performance of employees at PT Bank Negara Indonesia KCP Pamulang South Tangerang and determine the influence of organizational culture on employee performance, at PT Bank Negara Indonesia KCP Pamulang Tangerang Selatan. This type of research is associative descriptive research. The population and sample are all employees of PT Bank Negara Indonesia KCP Pamulang, South Tangerang. In this study carried out using the help of SPSS program ver. 23 that includes data quality tests, simple linear regression tests, correlation coefficient tests, hypothesis testing and coefficient of determination tests. The results of this study indicate that the organizational culture at PT Bank Negara Indonesia KCP Pamulang South Tangerang is already good, with answers from all respondents totaling 50 employees with "Strongly Agree" as much as 146 or 29\%, answers "Agree" as much as 262. Employee performance at PT. Bank Negara Indonesia KCP Pamulang, South Tangerang is already good, with the answers of all respondents totaling 50 employees who answered "Strongly Agree" as much as 177 or 35\%, answers "Agree" as much as 254 or 51\%. Organizational culture has a significant effect on employee performance at PT Bank Negara Indonesia KCP Pamulang Tangerang Selatan with a tcount greater than the ttable $(7.045>1.67)$ and a significance of less than $0.05(0.00<0.05)$.
\end{abstract}

Keywords : Organizational Culture, Employee Performance 


\section{PENDAHULUAN}

Perekembangan ekonomi negara-negara di dunia saat ini tengah berada dalam kondisi tertekan akibat dari pandemi virus corona (Covid-19). Aktivitas perekonomian negara maju diprediksi melambat seiring dengan pukulan yang terjadi baik dari sisi permintaan, penawaran, perdagangan hingga pasar keuangan. Perlambatan pertumbuhan ekonomi ini juga di alami oleh negara-negara asia termasuk Indonesia. Akibat dari perlambatan pertumbuhan ekonomi ini banyak perusahaan di Indonesia terpaksa harus merumahkan karyawannya.

Aktivitas di industri perbankan pun ikut terganggu akibat dari pandemi virus tersebut. Meskipun begitubankharustetap memberikanlayanan yang maksimal kepada seluruh nasabahnya selama pandemi berlangsung. Kualitas sumber daya manusia yang baik dibutuhkan untuk memberikan pelayanan yang memuaskan kepada nasabah. Sumber daya manusia merupakan salah satu faktor penting dalam perusahaan bahkan tidak dapat dilepaskan dari sebuah perusahaan. Sumber daya manusia juga merupakan kunci yang menentukan perkembangan perusahaan. Pada hakikatnya, sumber daya manusia berupa manusia yang dipekerjakan di sebuah perusahaan sebagai penggerak, pemikir dan perencana untuk mencapai tujuan perusahaan tersebut.

Manajemen sumber daya manusia digunakan untuk mengelola pegawai dalam pemenuhan tenaga kerja untuk mencapai tujuan perusahaan yang sudah direncanakan. Salah satu cara yang bisa digunakan untuk mengukur tercapainya tujuan perusahaan adalah dengan meningkatkan kinerja pegawainya. Kinerja dalam organisasi merupakan jawaban dari berhasil atau tidaknya tujuan organisasi yang telah ditetapkan Kinerja dapat juga di artikan sebagai sebuah prestasi yang dicapai oleh seorang karyawan dalam setiap melakukan pekerjaan atau tugasnya dengan segenap kemampuan, pengetahuan yang berbasis kompetensi Budaya organsasi merupakan salah sartu faktor yang dapat meningkatkan kinerja karyawan.

PT Bank Negara Indonesia merupakan salah satu lembaga keuangan milik pemerintah
(BUMN) dan juga salah satu bank komersial tertua di Indonesia. Perkembangan dunia perbankan saat ini yang semakin pesat membuat manajemen PT Bank Negara Indonesia harus meningkatkan juga kualitas sumber daya manusia yang dimiliki. Peningkatan kualitas sumber daya manusia sangat dibutuhkan untuk memberikan pelayanan yang optimal kepada nasabah sehingga tujuan perusahaan pun dapat tercapai sesuai dengan apa yang sudah direncanakan.

PT Bank Negara Indonesia selalu percaya bahwa karyawan merupakan salah satu aset paling berharga bagi perusahaan manapun. Keberlanjutan tidak akan mungkin dicapai tanpa andil dari pegawai. PT Bank Negara Indonesia pun berusaha menciptakan kondisi dan pengalaman bekerja terbaik untuk seluruh pegawai. PT Bank Negara Indonesia menginginkan setiap karyawan merasa bangga menjadi bagian dari keluarga perusahaan serta dapat berkarya dan menorehkan prestasi bersama. Tentunya, tanpa dedikasi dan kerja keras seluruh karyawan tidak akan mungkin tumbuh dengan baik dan mencapai keberlanjutan.

PT Bank Negara Indonesia KCP Pamulang Tangerang Selatan memiliki budaya kerja yakni prinsip yang diyakini dan menjadi landasan berbagai kebijakan pengelolaan sumber daya manusia serta menjadi panduan perilaku untuk setiap anggota perusahaan. Seluruh karyawan perusahaan mulai dari karyawan tetap maupun karyawan kontrak wajib mematuhi perilaku dan tata nilai budaya kerja ini. Perusahaan percaya melalui sosialisasi budaya kerja terus dilakukan kepada setiap karyawan karena perusahaan ingin memastikan seluruh karyawan memiliki pemahaman dan semangat yang sama untuk memberikan pelayanan terbaik kepada perusahaan.

Adapun tujuan dilakukan penelitian ini adalah untuk mengetahui bagaimana budaya organisasi pada PT Bank Negara Indonesia KCP Pamulang Tangerang Selatan, bagaimana kinerja karyawan pada PT Bank Negara Indonesia KCP Pamulang Tangerang Selatan serta bagaimana pengaruh budaya organisasi terhadap kinerja karyawan pada PT Bank Negara Indonesia KCP Pamulang, Tangerang Selatan. 


\section{METODE}

Penelitian ini merupakan jenis penelitian deskriptif asosiatif yaitu menggambarkan atau menjelaskan hubungan kausalitas antar variabel melalui suatu pengujian atau suatu perhitungan statistik didapat hasil pembuktian yang menunjukan hipotesis ditolak atau diterima.

Penelitian dilaksanakan di PT. Bank Negara Indonesia KCP Pamulang, Tangerang Selatan yang berlamat di Jl. Pamulang Permai Raya Blok SM. 21 Ciputat, Kota Tangerang Selatan, Banten Kode Pos 15417. Penelitian ini dilakukan mulai dari bulan Januari sampai dengan selesai yaitu meliputi pengajuan judul, penyebaran data dengan angket kuesioner, pengumpulan data hasil kuesioner serta penyajian dalam bentuk penelitian.

Di dalam operasional variabel penelitian, yang perlu dilakukan adalah menentukan faktorfaktor atau keadaan-keadaan yang dicakup dalam konsep penelitian ini, konsep-konsep yang akan dioperasionalkan sebagai berikut:

1. Budaya organisasi adalah suatu kekuatan sosial dapat berupa kebiasaan, yang mengandung nilai sehingga dapat menggerakan orang-orang dalam suatu organisasi atau perusahaan untuk melakukan aktivitas kerja.

2. Komitmen organisasi adalah keterlibatan seseorang yang relatif kuat terhadap organisasi yang mempunyai keinginan untuk tetap mempertahankan keanggotaannya dalam organisasi dan bersedia berusaha keras bagi pencapaian tujuan organisasi.

3. Kinerja adalah sebuah tindakan atau perilaku yang dilakukan oleh karyawan sebagai proses dalam mencapai tujuan organisasi sesuai dengan perannya dalam perusahaan.

\begin{tabular}{|c|c|c|c|}
\hline \multicolumn{4}{|c|}{ Tabel 1. Operasional Variabel Penelitian } \\
\hline Variabel & Indikator & Pernyataan & Skala \\
\hline \multirow{5}{*}{$\begin{array}{l}\text { Budaya } \\
\text { organisasi }\end{array}$} & $\begin{array}{l}\text { 1. Inovatif memperhitungkan } \\
\text { resiko }\end{array}$ & 1,2 & \multirow{5}{*}{ Likert } \\
\hline & $\begin{array}{l}\text { 2. Berorientasi pada hasil yang } \\
\text { dicapai }\end{array}$ & 3,4 & \\
\hline & $\begin{array}{l}\text { 3. Berorientasi kepada seluruh } \\
\text { kepentingan karyawan }\end{array}$ & 5,6 & \\
\hline & 4. Agresif dalam bekerja & 7,8 & \\
\hline & 5. Mempertahankan stabilitas kerja & 9,10 & \\
\hline
\end{tabular}

\begin{tabular}{|l|l|c|c|}
\hline \multirow{4}{*}{$\begin{array}{l}\text { Komitmen } \\
\text { Organisasi }\end{array}$} & 1. Komitmen Affektif & $1,2,3,4$ & \multirow{2}{*}{ Likert } \\
\cline { 2 - 3 } & 2. Komitmen Berkelanjutan & $5,6,7,8$ & \\
\cline { 2 - 3 } & 3. Komitmen Normatif & 9,10 & \\
\hline \multirow{4}{*}{$\begin{array}{c}\text { Kinerja } \\
\text { Karyawan }\end{array}$} & 1. Kualitas & 1,2 & \multirow{2}{*}{ Likert } \\
\cline { 2 - 3 } & 2. Kuantitas & 3,4 & \\
\cline { 2 - 4 } & 3. Ketepatan Waktu & 7,6 & \\
\cline { 2 - 4 } & 4. Efektivitas & 9,10 & \\
\cline { 2 - 4 } & 5. Kemandirian & \multicolumn{2}{|c}{ Sumber: Data Sekunder (data diolah) } \\
\hline
\end{tabular}

Dalam operasional variabel peneliti menggunakan skala ordinal. Skala ordinal digunakan untuk memberikan informasi nilai pada jawaban. Setiap variabel penelitian diukur dengan menggunakan instrumen pengukur dalam bentuk kuesioner berskala ordinal yang memenuhi pernyataan-pernyataan tipe skala likert.

Menurut Sugiyono (2017: 93) yang dimaksud dengan skala likert adalah untuk mengukur sikap, pendapat, dan persepsi seseorang atau sekelompok orang tentang fenomena sosial. Dalam penelitian, fenomena sosial ini telah ditetapkan secara spesifik oleh peneliti, yang selanjutnya disebut sebagai variabel penelitian.

\begin{tabular}{|c|c|}
\hline \multicolumn{2}{|c|}{ Tabel 2. Skala Nilai Alternatif Jawaban Kuesioner } \\
\hline Skala Likert & Skor Jawaban \\
\hline SS Sangat Setuju (SS) & 5 \\
\hline S Setuju & 4 \\
\hline R Ragu-ragu (R) & 3 \\
\hline TS Tidak Setuju (TS) & 2 \\
\hline Sangat Tidak Setuju (STS) & 1 \\
\hline
\end{tabular}

Populasi dan sampel yang digunakan dalam penelitian ini adalah seluruh karyawan PT Bank Negara Indonesai KCP Pamulang, Tangerang Selatan. Dalam penelitian ini data yang diperoleh dari hasil kuesioner kemudian dilakukan pengujian sebagai berikut:

\section{Uji Kualitas Data}

Yaitu uji validitas dan uji reliabilitas. Uji validitas digunakan untuk mengacu pada sejauh mana suatu instrumen dalam menjalankan fungsi. Dalam mencari nilai korelasi, peneliti menggunakan rumus korelasi product moment atau dikenal juga dengan korelasi pearson. Adapun rumusnya adalah sebagai berikut: 


$$
r x y=\frac{\mathbf{n}\left(\sum \mathbf{X X t}\right)-\left(\sum \mathbf{X}\right)\left(\sum \mathbf{X t}\right)}{\left.\sqrt{\left[\mathbf{n}\left(\sum \mathbf{X}^{2}\right)-\left(\sum \mathbf{X}\right)^{2}\right.}\right]\left[\mathbf{n}\left(\sum \mathbf{X t}^{2}\right)-\left(\sum \mathbf{X t}\right)^{2}\right]}
$$

Dengan kriteria penilaiannya adalah sebagai berikut:

- Jika nilai $\mathrm{r}_{\text {hitung }}$ lebih besar dari nilai $\mathrm{r}_{\text {tabel }}$ maka instrument angket dinyatakan $\operatorname{valid}\left(\mathrm{r}_{\text {hitung }}>\mathrm{r}_{\text {tabel }}\right.$ valid)

- Jika nilai $\mathrm{r}_{\text {hitung }}$ lebih kecil dari nilai rtabel maka instrument angket dinyatakan tidak valid ( $\mathrm{r}_{\text {hitung }}<\mathrm{r}_{\text {tabel }}$ Tidak valid).

Sedangkan uji reliabilitas digunakan untuk mengukur ketetapan atau keajegan alat tersebut dalam mengukur apa yang diukurnya. Rumus yang digunakan adalah menggunakan Cronbach Alpha:

$$
r 11=\left(\frac{k}{k-1}\right)\left(1-\frac{\Sigma S i}{S t}\right)
$$

Dengan ketentuan sebagai berikut:

- Jika $\mathrm{r}_{\text {hitung }}<\mathrm{r}_{\text {tabel }}$ (tabel product moment), maka tolok ukur tidak reliabel.

- Jika $\mathrm{r}_{\text {hitung }}>\mathrm{r}_{\text {tabel }}$ maka alat ukur reliabel.

\section{Uji Regresi Linier Sederhana}

Analisis regresi sederhana digunakan untuk melihat bagaimana pengaruh variabel bebas terhadap variabel terikat. Analisis ini digunakan untuk mengetahui arah hubungan antara variabel independen degan variabel dependen apakah positif atau negatif dan untuk memprediksi nilai dari variabel dependen apabila nilai variabel independen mengalami kenaikan atau penuruan. Adapun persamaan yang digunakan adalah sebagai berikut:

$$
\mathbf{Y}=\mathbf{a}+\mathbf{b X}
$$

\section{Keterangan:}

Y : Variabel dependen (nilai yang diprediksikan)

$\mathrm{X}$ : Variabel independent

a : Konstanta (nilai Y' apabila $\mathrm{X}=0$ )

b : Koefisien regresi (nilai peningkatan atau penurunan)

\section{Analisis Koefisien Korelasi}

Teknik yang digunakan untuk mencari hubungan dan membuktikan hipotesis hubungan dua variabel bila data variabel interval atau rasio dan sumber data dari variabel atau lebih adalah sama. Untuk dapat memberikan interprentasi seberapa kuat hubungan itu, maka dapat digunakan pedoman seperti pada tabel beriut ini:

\begin{tabular}{|c|c|}
\hline \multicolumn{2}{|c|}{ Tabel 3. Koefisien Korelasi } \\
\hline Interval Koefesien & Tingkat Hubungan \\
\hline $0,00-0,199$ & Sangat Rendah \\
\hline $0,20-0,399$ & Rendah \\
\hline $0,40-0,599$ & Sedang \\
\hline $0,60-0,799$ & Kuat \\
\hline $0,80-1,000$ & Sangat Kuat \\
\hline
\end{tabular}

\section{Uji Hipotesis (Uji Parsial atau uji t)}

Uji t dilakukan untuk mengetahui apakah variabel independen secara parsial mempengaruhi variabel dependen dengan asumsi varibel independen lainnya konstan.

$t_{\text {hitung }}=\frac{r_{x y} \sqrt{n-2}}{\sqrt{1-r_{x y}^{2}}}$

Adapun hipotesis yang digunakan dalah:

$\mathrm{H}_{0}$ : Terdapat pengaruh secara signifikan antara budaya organisasi dengan kinerja karyawan

$\mathrm{H}_{\mathrm{a}}$ : Tidak terdapat pengaruh secara signifikan antara budaya organisasi terhadap kinerja karyawan.

Kriteria yang digunakan adalah:

- Jika nilai signifikan >0,05 maka hipotesis ditolak (koefisien regresi tidak signifikan). Ini berarti bahwa variabel independen tersebut tidak mempunyai pengaruh yang signifikan terhadap variabel dependen.

- Jika nilai signifikan $<0,05$ maka hipotesis diterima (koefisien regresi signifikan). Ini berarti variabel independen tersebut mempunyai pengaruh yang signifikan terhadap variabel dependen. 


\section{Uji Koefisien Determinasi}

Uji ini digunakan untuk menghitung seberapa besar persen konstribusi variabel bebas (budaya organisasi) dan terhadap variabel terikat (kinerja karyawan). Besarnya nilai koefisien determinasi adalah antara 0 (nol) sampai dengan 1 (satu). Jika hasil dari uji koefisien determinasi adalah nol maka dapat diartikan bahwa variabel bebas sama sekali tidak mempengaruhi variabel terikat. Adapun rumus yang digunakan untuk menghitung nilai koefisien determinasi adalah sebagai berikut:

$$
\mathrm{KD}=\left(\mathbf{r}_{\mathrm{xy}}\right)^{2}
$$

\section{HASIL dan PEMBAHASAN}

Hasil

\section{Karakteristik Responden}

Untuk mempermudah dalam mengidentifikasi responden dalam penelitian ini, maka diperlukan gambaran mengenai karakteristik responden. Adapun gambaran karakteristik responden dalam penelitian ini adalah sebagai berikut:

\section{a. Karakteristik Responden Berdasarkan Jenis Kelamin}

Berikut adalah data mengenai jenis kelamin responden atau karyawan PT Bank Bank Negara Indonesia KCP Pamulang, Tangerang Selatan:

\begin{tabular}{|l|c|c|}
\hline \multicolumn{2}{|c|}{ Tabel 4. Karakteristik Responden Berdasarkan Jenis Kelamin } \\
\hline \multicolumn{1}{|c|}{ Jenis Kelamin } & Jumlah & Persentase \\
\hline Laki-laki & 32 & $64 \%$ \\
\hline Perempuan & 18 & $36 \%$ \\
\hline Total & 50 & $100 \%$ \\
\hline \multicolumn{3}{r}{ Sumber: Data Primer (diolah) } \\
\hline
\end{tabular}

Berdasarkan tabel di atas dapat diketahui bahwa responden berdasarkan jenis kelamin didominasi oleh laki-laki yaitu sebanyak 32 orang atau sebesar $64 \%$ dan responden dengan jenis kelamin perempuan sebanyak 18 orang atau sebesar 36\%.

b. Karakteristik Responden Berdasarkan Usia

Berikut adalah data mengenai usia res- ponden atau karyawan PT Bank Bank Negara Indonesia KCP Pamulang, Tangerang Selatan:

\begin{tabular}{|l|c|c|}
\hline \multicolumn{1}{|c|}{ Tabel 5. Karakteristik Responden Berdasarkan Usia } \\
\begin{tabular}{|l|c|c|}
\hline \multicolumn{1}{|c|}{ Usia } & Jumlah & Persentase \\
\hline Usia < 20 tahun & 2 & $4 \%$ \\
\hline Usia 20 - 30 tahun & 26 & $52 \%$ \\
\hline Usia 31 - 40 tahun & 14 & $28 \%$ \\
\hline Usia > 40 tahun & 8 & $16 \%$ \\
\hline Total & 50 & $100 \%$ \\
\hline \multicolumn{3}{|c|}{ Sumber: Data Primer (diolah) } \\
\hline
\end{tabular}
\end{tabular}

Berdasarkan tabel di atas dapat diketahui bahwa jumlah responden dengan usia kurang dari 20 tahun sebanyak 2 orang atau sebesar $4 \%$, responden denga usia 20-30 tahun sebanyak 26 orang atau sebesar 52\%, responden dengan usia 3140 tahun sebanyak 14 orang atau sebesar $28 \%$ dan responden dengan usia lebih dari 40 tahun sebanyak 8 orang atau sebesar 16\%. Jadi dapat disimpulkan bahwa responden berdasarkan usia didominasi antara 20-30 tahun yaitu sebanyak 26 orang atau sebesar $52 \%$.

c. Karakteristik Responden Berdasarkan Gaji

Berikut adalah data mengenai gaji yang diterima responden atau karyawan PT Bank Bank Negara Indonesia KCP Pamulang, Tangerang Selatan:

\begin{tabular}{|l|c|c|}
\hline \multicolumn{1}{|c|}{ Tabel 6. Karakteristik Responden Berdasarkan Gaji } \\
\hline \multicolumn{1}{|c|}{ Gaji } & Jumlah & Persentase \\
\hline$<$ Rp3.000.000 & 2 & $4 \%$ \\
\hline Rp3.000.001-Rp4.000.000 & 18 & $36 \%$ \\
\hline Rp4.000.001-Rp5.000.000 & 24 & $48 \%$ \\
\hline$>$ Rp5.000.000 & 6 & $12 \%$ \\
\hline Total & 50 & $100 \%$ \\
\hline \multicolumn{2}{|c|}{ Sumber: Data Primer (diolah) } \\
\hline
\end{tabular}

Berdasarkan tabel di atas dapat diketahui bahwa responden dengan jumlah gaji kurang dari Rp3.000.000 adalah sebanyak 2 orang atau sebesar $4 \%$, responden dengan gaji Rp3.000.001Rp4.000.000 sebanyak 18 orang atau sebesar 36\%, responden dengan gaji Rp4.000.001-Rp5.000.000 sebanyak 24 orang atau sebesar $48 \%$ dan respon- 
den dengan jumlah gaji lebih dari Rp5.000.000 sebanyak 6 orang atau sebesar $12 \%$. Jadi dapat disimpulkan bahwa responden berdasarkan jumlah gaji mayoritas kisaran antara Rp4.000.001Rp5.000.000 yaitu sebanyak 24 orang atau sebesar $48 \%$.

\section{d. Karakteristik Responden Berdasarkan} Pendidikan

Berikut adalah data mengenai pendidikan terakhir responden atau karyawan PT Bank Bank Negara Indonesia KCP Pamulang, Tangerang Selatan:

Tabel 7. Karakteristik Responden Berdasarkan Pendidikan

\begin{tabular}{|l|c|c|}
\hline \multicolumn{1}{|c|}{ Pendidikan } & Jumlah & Persentase \\
\hline SMA atau Sederajat & 11 & $22 \%$ \\
\hline D3 & 12 & $24 \%$ \\
\hline S1 & 26 & $52 \%$ \\
\hline S2 & 1 & $2 \%$ \\
\hline Total & 50 & $100 \%$ \\
\hline \multicolumn{2}{|c|}{ Sumber: Data Primer (diolah) } \\
\hline
\end{tabular}

Berdasarkan tabel di atas dapat diketahui bahwa responden atau karyawan PT Bank Bank Negara Indonesia KCP Pamulang, Tangerang Selatan mayoritas adalah dengan pendidikan $S 1$ yaitu dengan jumlah sebanyak 26 orang atau sebesar 52\%, responden dengan pendidikan SMA atau sederajat sebanyak 11 orang atau sebesar $22 \%$, responden dengan pendidikan D3 sebanyak 12 orang atau sebesar $24 \%$, dan responden dengan pendidikan $\mathrm{S} 1$ hanya 1 orang atau sebesar $2 \%$ dari total seluruh responden.

\section{Distribusi Jawaban Responden}

Dalam penelitian ini terdapat 2 variabel bebas yaitu budaya organisasi (X) serta variabel terikat yaitu kinerja karyawan (Y). Untuk mengetahui distribusi jawaban responden pada masing-masing variabel berdasarkan kuesioner yang telah diberikan, dapat disajikan seperti pada tabel berikut ini:

a. Distribusi Jawaban Responden Variabel Budaya Organisasi $(\mathrm{X})$

Berikut adalah data mengenai distribusi jawaban responden terhadap variabel
X (budaya organisasi) pada PT Bank Bank Negara Indonesia KCP Pamulang, Tangerang Selatan:

\begin{tabular}{|l|c|c|c|c|c|c|}
\hline \multicolumn{7}{c}{ Tabel 8. Distribusi Jawaban Responden Variabel X } \\
\hline \multirow{2}{*}{ Pernyataan } & \multicolumn{5}{c}{ Jawaban } & \multirow{2}{*}{ Jumlah } \\
\cline { 2 - 6 } & STS & TS & R & SS & SS & \\
\hline Pernyataan 1 & 0 & 0 & 9 & 25 & 16 & 50 \\
\hline Pernyataan 2 & 0 & 0 & 19 & 17 & 14 & 50 \\
\hline Pernyataan 3 & 0 & 0 & 6 & 33 & 11 & 50 \\
\hline Pernyataan 4 & 0 & 0 & 15 & 27 & 8 & 50 \\
\hline Pernyataan 5 & 0 & 0 & 2 & 26 & 22 & 50 \\
\hline Pernyataan 6 & 0 & 0 & 7 & 31 & 12 & 50 \\
\hline Pernyataan 7 & 0 & 0 & 3 & 32 & 15 & 50 \\
\hline Pernyataan 8 & 0 & 0 & 11 & 27 & 12 & 50 \\
\hline Pernyataan 9 & 0 & 2 & 9 & 19 & 20 & 50 \\
\hline Pernyataan 10 & 0 & 0 & 9 & 25 & 16 & 50 \\
\hline Jumlah & 0 & 2 & 90 & 262 & 146 & 500 \\
\hline Persentase & $0 \%$ & $1 \%$ & $18 \%$ & $52 \%$ & $29 \%$ & $100 \%$ \\
\hline & & & Sumber: Data Primer (diolah) \\
\hline
\end{tabular}

Berdasarkan tabel di atas dapat diketahui bahwa bahwa budaya organisasi karyawan pada PT Bank Bank Negara Indonesia KCP Pamulang, Tangerang Selatan sudah baik. Jawaban seluruh responden yang berjumlah 50 karyawan dengan 10 pernyataan, yang menjawab "Sangat Setuju" sebanyak 146 atau 29\%, jawaban "Setuju" sebanyak 262 atau $52 \%$, jawaban "Ragu" sebanyak 90 atau $18 \%$, jawaban "Tidak Setuju” sebanyak 2 atau 1\% dan jawaban "Sangat Tidak Setuju” sebanyak 0 atau $0 \%$.

b. Distribusi Jawaban Responden Variabel Kinerja (Y)

Berikut adalah data mengenai distribusi jawaban responden terhadap variabel Y (kinerja karyawan) pada PT Bank Bank Negara Indonesia KCP Pamulang, Tangerang Selatan:

\begin{tabular}{|l|c|c|c|c|c|c|}
\hline \multirow{2}{*}{ Tabel 9. Distribusi Jawaban Responden Variabel Y } \\
\cline { 2 - 7 } Pernyataan & \multicolumn{7}{|c|}{ Jawaban } & \multirow{2}{*}{ Jumlah } \\
\cline { 2 - 7 } & STS & TS & R & SS & SS & \\
\hline Pernyataan 1 & 0 & 0 & 7 & 28 & 15 & 50 \\
\hline Pernyataan 2 & 0 & 0 & 10 & 23 & 17 & 50 \\
\hline Pernyataan 3 & 0 & 1 & 3 & 24 & 22 & 50 \\
\hline Pernyataan 4 & 0 & 1 & 6 & 31 & 12 & 50 \\
\hline Pernyataan 5 & 0 & 0 & 11 & 25 & 14 & 50 \\
\hline
\end{tabular}




\begin{tabular}{|l|c|c|c|c|c|c|}
\hline Pernyataan 6 & 0 & 1 & 2 & 22 & 25 & 50 \\
\hline Pernyataan 7 & 0 & 2 & 9 & 19 & 20 & 50 \\
\hline Pernyataan 8 & 0 & 0 & 3 & 27 & 20 & 50 \\
\hline Pernyataan 9 & 0 & 1 & 5 & 30 & 14 & 50 \\
\hline Pernyataan 10 & 0 & 1 & 6 & 25 & 18 & 50 \\
\hline Jumlah & 0 & 7 & 62 & 254 & 177 & 500 \\
\hline Persentase & $0 \%$ & $2 \%$ & $12 \%$ & $51 \%$ & $35 \%$ & $100 \%$ \\
\hline
\end{tabular}

Berdasarkan tabel di atas dapat diketahui bahwa bahwa kinerja karyawan pada PT Bank Bank Negara Indonesia KCP Pamulang, Tangerang Selatan sudah baik. Jawaban seluruh responden yang berjumlah 50 karyawan dengan 10 pernyataan, yang menjawab "Sangat Setuju" sebanyak 177 atau 35\%, jawaban "Setuju" sebanyak 254 atau 51\%, jawaban "Ragu" sebanyak 62 atau 12\%, jawaban "Tidak Setuju" sebanyak 7 atau 2\% dan jawaban "Sangat Tidak Setuju" sebanyak 0 atau $0 \%$.

\section{Uji Kualitas Data}

Dalam penelitian ini uji kualitas data yang digunakan adalah uji validitas dan uji reliabilitas. Berikut adalah hasil pengujian validitas dan reliabilitas variabel:

\section{a. Uji Validitas}

Untuk melakukan pengujian $r_{\text {hitung }}$ digunakan dengan rumus product moment atau sering dinamakan dengan pearson. Teknik pengujian dengan membandingkan $r_{\text {hitung }}$ dengan $r_{\text {tabel }}$. Apabila $r_{\text {hitung }}>r_{\text {tabel }}$ maka pernyataan tersebut dinyatakan valid

\begin{tabular}{|l|c|c|c|}
\hline \multicolumn{4}{|c|}{ Tabel 10. Uji Validitas Variabel X } \\
\hline Pernyataan & $\mathbf{r}_{\text {hitung }}$ & $\mathbf{r}_{\text {tabel }}$ & Kesimpulan \\
\hline Pernyataan 1 & 0,352 & 0,278 & Valid \\
\hline Pernyataan 2 & 0,466 & 0,278 & Valid \\
\hline Pernyataan 3 & 0,446 & 0,278 & Valid \\
\hline Pernyataan 4 & 0,514 & 0,278 & Valid \\
\hline Pernyataan 5 & 0,592 & 0,278 & Valid \\
\hline Pernyataan 6 & 0,749 & 0,278 & Valid \\
\hline Pernyataan 7 & 0,410 & 0,278 & Valid \\
\hline Pernyataan 8 & 0,578 & 0,278 & Valid \\
\hline Pernyataan 9 & 0,674 & 0,278 & Valid \\
\hline Pernyataan 10 & 0,318 & 0,278 & Valid \\
\hline
\end{tabular}

Berdasarkan tabel di atas dapat diketahui bahwa semua item pernyataan pada variabel bebas (budaya organisasi) adalah nilai $r_{\text {hitung }}$ lebih besar dari nilai $\mathrm{r}_{\text {tabel }}$ Nilai $\mathrm{r}_{\text {tabel }}$ diperoleh dari rumus N-2 (50-2=48) sehingga didapatkan nilai $\mathrm{r}_{\text {tabel }}$ sebesar 0,278. Karena nilai $r_{\text {hitung }}>r_{\text {tabel }}$ jadi dapat disimpulkan bahwa semua item pernyataan pada vaiabel budaya organisasi yang digunakan dalam penelitian ini adalah valid.

\begin{tabular}{|l|c|c|c|}
\hline \multicolumn{1}{|c|}{ Tabel 11. Uji Validitas Variabel Y } \\
\hline Pernyataan & $\mathbf{r}_{\text {hitung }}$ & $\mathbf{r}_{\text {tabel }}$ & Kesimpulan \\
\hline Pernyataan 1 & 0,333 & 0,278 & Valid \\
\hline Pernyataan 2 & 0,506 & 0,278 & Valid \\
\hline Pernyataan 3 & 0,295 & 0,278 & Valid \\
\hline Pernyataan 4 & 0,475 & 0,278 & Valid \\
\hline Pernyataan 5 & 0,324 & 0,278 & Valid \\
\hline Pernyataan 6 & 0,565 & 0,278 & Valid \\
\hline Pernyataan 7 & 0,499 & 0,278 & Valid \\
\hline Pernyataan 8 & 0,441 & 0,278 & Valid \\
\hline Pernyataan 9 & 0,619 & 0,278 & Valid \\
\hline Pernyataan 10 & 0,397 & 0,278 & Valid \\
\hline
\end{tabular}

Berdasarkan tabel di atas dapat diketahui bahwa semua item pernyataan pada vaiabel terikat (kinerja karyawan) adalah nilai $\mathrm{r}_{\text {hitung }}$ lebih besar dari nilai $\mathrm{r}_{\text {tabel }}$ Nilai $\mathrm{r}_{\text {tabel }}$ diperoleh dari rumus $\mathrm{N}-2$ $(50-2=48)$ sehingga didapatkan nilai $\mathrm{r}_{\text {tabel }}$ sebesar 0,278. Karena nilai $\mathrm{r}_{\text {hitung }}$ $>\mathrm{r}_{\text {tabel }}$ jadi dapat disimpulkan bahwa semua item pernyataan yang digunakan pada variabel kinerja karyawan dalam penelitian ini adalah valid.

\section{b. Uji Reliabilitas}

Uji reliabilitas digunakan untuk menentukan apakah kuesioner tetap konsisten apabila digunakan lebih dari satu kali terhadap gejala yang sama dengan alat ukur yang sama. Uji statistik Cronbach Alpha digunakan untuk menguji tingkat reliabel suatu variabel. Suatu variabel dikatakan reliabel jika nilai Cronbach Alpha $>\mathrm{r}_{\text {tabel }}$ 


\begin{tabular}{|l|c|c|c|}
\hline \multicolumn{1}{|c|}{ Tabel 12. Uji Reliabilitas Variabel } \\
\hline Budaya organisasi & Cronbach Alpha & $r_{\text {tabel }}$ & Kesimpulan \\
\hline Kinerja Karyawan & 0,718 & 0,278 & Reliabel \\
\hline
\end{tabular}

Berdasarkan tabel di atas pengujian reliabilitas terhadap variabel budaya organisasi, komitmen organisasi dan kinerja karyawan dapat diketahui bahwa nilai Cronbach Alpha semua baik variabel bebas (budaya organisasi) maupun variabel terikat (kinerja karyawan) adalah diatas $r_{\text {tabel }}$ Maka dapat disimpulkan semua variabel yang digunakan dalam penelitian ini adalah reliabel.

\section{Uji Regresi Linier Sederhana}

\begin{tabular}{|c|c|c|c|c|c|c|}
\hline \multicolumn{7}{|c|}{ Tabel 13. Uji Regresi Linier Sederhana } \\
\hline \multirow{2}{*}{\multicolumn{2}{|c|}{ Model }} & \multicolumn{2}{|c|}{$\begin{array}{l}\text { Unstandardized } \\
\text { Coefficients }\end{array}$} & \multirow{2}{*}{$\begin{array}{c}\text { Standardized } \\
\text { Coefficients } \\
\text { Beta }\end{array}$} & \multirow{2}{*}{$\mathrm{t}$} & \multirow{2}{*}{ Sig. } \\
\hline & & B & $\begin{array}{c}\text { Std. } \\
\text { Error }\end{array}$ & & & \\
\hline \multirow{2}{*}{1} & (Constant) & 18.408 & 4.084 & & 4.507 & .000 \\
\hline & Budaya & .575 & .099 & .642 & 5.801 & .000 \\
\hline
\end{tabular}

Dari tabel di atas diperoleh persamaan atau model regresi untuk kinerja karyawan sebagai berikut:

$$
\mathbf{Y}=\mathbf{a}+\mathbf{b X}
$$

Dari persamaan tersebut dapat diambil kesimpulan sebagai berikut:

a. Konstanta sebesar 18,408 menyatakan bahwa jika budaya organisasi (X) bernilai 0 (nol), maka kinerja karyawan (Y) nilainya sebesar 18,408

b. Koefisien regresi budaya organisasi (X) sebesar 0,575 menyatakan bahwa setiap penambahan $1 \%$ variabel budaya organisasi, maka akan menaikan kinerja karyawan sebesar 0,575.

Koefisien bernilai positif artinya terjadi hubungan positif antara budaya organisasi dengan kinerja karyawan, semakin naik budaya organisasi maka semakin meningkatkan kinerja karyawan.

\section{Uji Koefisien Korelasi}

Uji koefisien korelasi digunakan untuk me- lihat nilai yang menunjukkan kuat atau tidaknya hubungan antar variabel. Semakin mendekati angka 1 maka hubungan antar variabel tersebut sangat kuat, sebaliknya semakin menjauhi angka 1 maka hubungan antar variabel tersebut semakin lemah.

\begin{tabular}{|c|c|c|}
\hline \multicolumn{3}{|c|}{ Tabel 14. Uji Koefisien Korelasi } \\
\hline Variabel & Pearson Correlation (Y) & Kesimpulan \\
\hline Budaya Organisasi & 0,642 & Kuat \\
\hline
\end{tabular}

Berdasarkan tabel di atas dapat diketahui bahwa nilai pearson correlation 0,642 untuk variabel budaya organisasi terhadap kinerja karyawan. Nilai tersebut berada pada interval koefisien 0,60-0,799 (kuat). Jadi dapat disimpulkan bahwa hubungan antara budaya organisasi dengan kinerja karyawan adalah kuat.

\section{Uji Hipotesis (uji-t)}

Uji hipotesis dalam penelitian ini digunakan untuk mengetahu pengaruh variabel bebas (X) yaitu budaya organisasi terhadap variabel terikat (Y) yaitu kinerja karyawan.

\begin{tabular}{|c|c|c|c|c|c|c|}
\hline \multicolumn{7}{|c|}{ Tabel 15. Uji t X terhadap Y } \\
\hline \multirow{2}{*}{\multicolumn{2}{|c|}{ Model }} & \multicolumn{2}{|c|}{$\begin{array}{l}\text { Unstandardized } \\
\text { Coefficients }\end{array}$} & \multirow{2}{*}{$\begin{array}{c}\text { Standardized } \\
\text { Coefficients }\end{array}$} & \multirow{2}{*}{$t$} & \multirow{2}{*}{ Sig. } \\
\hline & & B & $\begin{array}{l}\text { Std. } \\
\text { Error }\end{array}$ & & & \\
\hline \multirow{2}{*}{1} & (Constant) & 18.408 & 4.084 & & 4.507 & .000 \\
\hline & $X_{1}$ & .575 & .099 & .642 & 5.801 & .000 \\
\hline & endent Var & & & & & \\
\hline
\end{tabular}

Berdasarkan tabel di atas diperoleh nilai $\mathrm{t}_{\text {hitung }}$ $>\mathrm{t}_{\text {tabel }}(7,045>1,67)$ dan nilai signifikansi $<$ $0,05(0,000<0,05)$ maka dapat disimpulkan bahwa budaya organisasi secara parsial berpengaruh positif dan signifikan terhadap kinerja karyawan pada PT Bank Negara Indonesia KCP Pamulang, Tangerang Selatan.

\section{Uji Koefisien Determinasi}

\begin{tabular}{l|c|c|c|c|}
\hline \multicolumn{5}{|c|}{ Tabel 16. Uji Koefisien Determinasi } \\
\hline Model & R & R Square & $\begin{array}{c}\text { Adjusted R } \\
\text { Square }\end{array}$ & $\begin{array}{c}\text { Std. Error of the } \\
\text { Estimate }\end{array}$ \\
\hline 1 & $.642^{\mathrm{a}}$ & .412 & .400 & 2.39654 \\
\hline \multicolumn{3}{|c|}{ a. Predictors: (Constant), Budaya } \\
\hline
\end{tabular}

Berdasarkan tabel di atas diketahui nilai $R$-Square $\left(\mathrm{r}^{2}\right)$ sebesar 0,412 atau $41,2 \%$. Jadi dapat disimpulkan bahwa budaya organisasi 
mempengaruhi kinerja karyawan sebesar $41,2 \%$, sedangkan sisanya sebesar $58,8 \%$ dipengaruhi oleh faktor lain.

\section{Pembahasan}

Budaya organisasi Pada PT. Bank Negara Indonesia KCP Pamulang, Tangerang Selatan

Berdasarkan hasil kuesioner yang telah dilakukan kepada 50 orang responden didapatkan hasil bahwa budaya organisasi karyawan PT Bank Negara Indonesia KCP Pamulang, Tangerang Selatan sudah baik. Penulis menyimpulkan bahwa berdasarkan hasil jawaban seluruh responden terhadap 10 pernyataan pada variabel budaya organisasi yang menjawab "Sangat Setuju" sebanyak 146 atau 29\%, jawaban "Setuju" sebanyak 262 atau 52\%, jawaban "Ragu" sebanyak 90 atau $18 \%$, jawaban "Tidak Setuju" sebanyak 2 atau 1\% dan jawaban "Sangat Tidak Setuju" sebanyak 0 atau $0 \%$.

\section{Kinerja Karyawan Pada PT Bank Negara Indonesia KCP Pamulang, Tangerang Selatan}

Berdasarkan hasil kuesioner yang telah dilakukan kepada 50 orang responden didapatkan hasil bahwa kinerja karyawan PT Bank Negara Indonesia KCP Pamulang, Tangerang Selatan sudah baik. Penulis menyimpulkan bahwa berdasarkan hasil jawaban seluruh responden terhadap 10 pernyataan pada variabel kinerja yang menjawab "Sangat Setuju” sebanyak 177 atau 35\%, jawaban "Setuju” sebanyak 254 atau 51\%, jawaban "Ragu" sebanyak 62 atau 12\%, jawaban "Tidak Setuju" sebanyak 7 atau 2\% dan jawaban "Sangat Tidak Setuju" sebanyak 0 atau $0 \%$.

\section{Pengaruh Budaya Organisasi terhadap Kinerja Karyawan pada PT Bank Negara Indonesia KCP Pamulang, Tangerang Selatan}

Dari pengujian hipotesis $t_{\text {hitung }}$ sebesar 5,801 dengan nilai signifikasi 0,000 dan $\mathrm{t}_{\text {tabel }}$ 1,67. Karena $\mathrm{t}_{\text {hitung }}>\mathrm{t}_{\text {tabel }}(7,045>1,67)$ dan nilai signifikansi $<$ $0,05(0,000<0,05)$ maka dapat disimpulkan bahwa budaya organisasi secara berpengaruh positif dan signifikan terhadap kinerja karyawan pada PT Bank Negara Indonesia KCP Pamulang, Tangerang Selatan.

\section{SIMPULAN}

Budaya organisasi pada PT Bank Negara Indonesia KCP Pamulang, Tangerang Selatan sudah baik. Hal ini dibuktikan dengan hasil jawaban responden terhadap 10 pernyataan pada variabel budaya organisasi yang menjawab "Sangat Setuju" sebanyak 146 atau 29\%, jawaban "Setuju" sebanyak 262 atau 52\%. Kinerja karyawan PT Bank Negara Indonesia KCP Pamulang, Tangerang Selatan sudah baik. Hal ini dibuktikan berdasarkan hasil jawaban seluruh responden terhadap 10 pernyataan pada variabel kinerja yang menjawab "Sangat Setuju" sebanyak 177 atau 35\%, jawaban "Setuju" sebanyak 254 atau $51 \%$. Budaya organisasi berpengaruh signifikan terhadap kinerja karyawan pada PT Bank Negara Indonesia KCP Pamulang, Tangerang Selatan. Hal ini dibuktikan dengan nilai $t_{\text {hitung }}$ lebih besar dari nilai $\mathrm{t}_{\text {tabel }}(7,045>1,67)$ dan signifikansi lebih kecil dari $0,05(0,00<0,05)$.

\section{PENGHARGAAN}

Ucapan terima kasih dan penghargaan yang setinggi-tingginya kepada Kemenristekdikti yang sudah memberikan sumber pembiayaan terhadap riset peneliti, IPPM, Bank BNI sebagai objek yang diteliti dan kepada anggota tim penyusun serta pihak-pihak yang telah berperan hingga selesainya penelitian ini.

\section{DAFTAR PUSTAKA}

Arifin, N. (2018). Manajemen Sumber Daya Manusia, Teori dan Kasus. Jepara: Unisnu Press.

Bandari, A. S. (2016). Peranan Pelatihan Dalam Meningkatkan Kinerja Karyawan Pada Unit Perencanaan PDAM Tirta Musi Rambutan. Palembang: Politeknik Negeri Sriwijaya.

Busro, M. (2018). Teori-teori Manajemen Sumber

Daya Manusia. Jakarta: Prenadamedia Group.

Darmadi. (2018). Manajemen Sumber Daya Manusia Kekepalasekolahan. Yogyakarta: Deepublish.

Elbadiansyah. (2019). Manajemen Sumber Daya Manusia, Cetakan Kesatu. Malang: IRDH. 
Indrasari, M. (2017). Kepuasan Kerja dan Kinerja Karyawan. Yogyakarta: Indomedia Pustaka.

Kaswan. (2015). Sikap Kerja: Dari Teori Implementasi Sampai Bukti. Bandung: Alfabeta.

Kristanti, D. d. (2019). Pengaruh Stres Kerja, Motivasi Kerja, dan Lingkungan Kerja Terhadap Kinerja Karyawan Bagian Produksi (Studi di UD Pratama Karya Kota Kediri). Jurnal Bisnis dan Keuangan, 105-114.

Manery, B. R. (2018). Pengaruh Komitmen Organisasi dan Budaya Organisasi Terhdap Kinerja Pegawai di BKDPSDA Di Kabupaten Halmahera Utara. Jurnal EMBA, 1968-1977.

Mattalata, R. d. (2018). Rismawati, Mattalata. (2018). Evaluasi Kinerja Penilaian Kinerja Atas Dasar Prestasi Kerja Berorientasi Kedepan. Makassar: Celebes Media Perkasa.

Meutia, K. I. (2019). Pengaruh Budaya Organisasi dan Komitmen Organisasi Terhadap Kinerja Karyawan. Jurnal Riset Manajemen dan Bisnis, 119-126.

Muis, M. R. (2018). Pengaruh Budaya Organisasi Dan Komitmen Organisasi Terhadap Kinerja Karyawan. Jurnal Ekonomi dan Ekonomi Syariah, 9-25.
Pratama, A. (2018). Pengaruh Komitmen Organisasi dan Kompensasi Terhadap Kepuasan Kerja Serta Dampaknya Terhadap Kinerja Karyawan (Pada Sub Direktorat Penindakan Bea dan Cukai. Jurnal Ilmiah Semarak, 122141.

Pratama, A. (2020). Pengaruh Kompensasi dan Disiplin Kerja Terhadap Kinerja Karyawan Pada PT Pos Indonesia DC Ciputat. Jurnal Disrupsi Bisnis, 12-24.

Setyanti, E. (2018). Komitmen Pada Perubahan Organisasi (Perubahan Organisasi dalam Perspektif Islam). Sleman: CV. Budi Utama.

Sulaksono. (2015). Budaya Organisasi dan Kinerja. Sleman: CV. Budi Utama.

Sutrisno. (2017). Manajemen Sumber Daya Manusia, Cetakan Ke-9. Jakarta: Kencana.

Tanuwibowo, J. C. (2014). Hubungan Budaya Organisasi dan Komitmen Organisasi Pada Kinerja Karyawan. Jurnal Trikonomika, 136144.

Tobari. (2015). Membangun Budaya Organisasi Pada Instansi Pemerintahan. Sleman: CV. Budi Utama. 